'Investigating the impact of workplace bullying on employees' morale, performance and turnover intentions in five-star Egyptian hotel operations"

\begin{tabular}{|c|c|}
\hline AUTHORS & $\begin{array}{l}\text { Ashraf Tag-Eldeen } \\
\text { Mona Barakat } \\
\text { Hesham Dar }\end{array}$ \\
\hline ARTICLE INFO & $\begin{array}{l}\text { Ashraf Tag-Eldeen, Mona Barakat and Hesham Dar (2017). Investigating the } \\
\text { impact of workplace bullying on employees' morale, performance and turnover } \\
\text { intentions in five-star Egyptian hotel operations. Tourism and Travelling, 1(1), 4- } \\
\text { 14. doi:10.21511/tt.1(1).2017.01 }\end{array}$ \\
\hline DOI & http://dx.doi.org/10.21511/tt.1(1).2017.01 \\
\hline RELEASED ON & Tuesday, 26 December 2017 \\
\hline RECEIVED ON & Tuesday, 06 June 2017 \\
\hline \multirow[t]{2}{*}{ ACCEPTED ON } & Wednesday, 05 July 2017 \\
\hline & $(\mathrm{cc}) \overline{\mathrm{EY}-\mathrm{NC}}$ \\
\hline LICENSE & $\begin{array}{l}\text { This work is licensed under a Creative Commons Attribution-NonCommercial } 4.0 \\
\text { International License }\end{array}$ \\
\hline JOURNAL & "Tourism and Travelling" \\
\hline ISSN PRINT & $2544-2295$ \\
\hline PUBLISHER & LLC “Consulting Publishing Company "Business Perspectives" \\
\hline FOUNDER & Sp. z o.o. Kozmenko Science Publishing \\
\hline
\end{tabular}

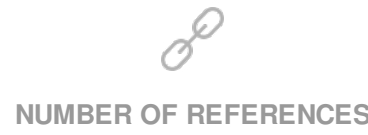

61
NUMBER OF FIGURES

1
ニニ:-

NUMBER OF TABLES

4

(C) The author(s) 2023. This publication is an open access article. 


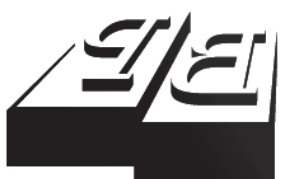

BUSINESS PERSPECTIVES

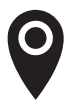

LLC "CPC "Business Perspectives" Hryhorii Skovoroda lane, 10, Sumy, 40022, Ukraine

www.businessperspectives.org
Received on: $6^{\text {th }}$ of June, 2017 Accepted on: $5^{\text {th }}$ of July, 2017

(C) Ashraf Tag-Eldeen, Mona Barakat, Hesham Dar, 2017

Ashraf Tag-Eldeen, Ph.D., Professor, Business Administration/Hotel Management, SRH-Hochschule Berlin, Germany.

Mona Barakat, Ph.D., Professor, Hotel Management, Alexandria University, Egypt.

Hesham Dar, M.Sc., Assistant Lecturer, Hotel Management, Alexandria University, Egypt.

\section{(ㄷ)(1) $\$$}

This is an Open Access article, distributed under the terms of the Creative Commons Attribution-NonCommercial 4.0 International license, which permits re-use, distribution, and reproduction, provided the materials aren't used for commercial purposes and the original work is properly cited.

\title{
INVESTIGATING THE IMPACT OF WORKPLACE BULLYING ON EMPLOYEES' MORALE, PERFORMANCE AND TURNOVER INTENTIONS IN FIVE-STAR EGYPTIAN HOTEL OPERATIONS
}

\begin{abstract}
In today's competitive business environment, human resources are one of the most critical assets particularly for service-focused organizations. Consequently, employees' morale has become invaluable for maintaining outstanding organizational performance and retaining employees. One of the most important factors which may affect employees' satisfaction is workplace bullying from employers and colleagues at large. It is considered a negative and unethical issue which may degrade, humiliate and create a risk to a healthy working environment. Therefore, the main objective of this research is to investigate the extent to which workplace bullying may affect the organizational outcomes of a sample of five-star hotels in Egypt. Two questionnaires were distributed among the subjects of the sample; bell desk staff, kitchen stewards and head departments. The results of this research confirmed that there is a correlation between workplace bullying, employees' morale and turnover intentions but, showed no correlation between workplace bullying and employees' work performance.
\end{abstract}

\section{Keywords}

\section{JEL Classification}

\section{INTRODUCTION}

Managing organizational resources is a vital aspect in the success of any organization in today's business world. It is established that human resource is the most critical factor in this respect. Nadiri \& Tanova (2010) stated that human resources play a central role and demand special attention. It is recognised as the main differentiating success factor for most organizations especially for the servicefocused organizations. Therefore, the challenge facing most organizations is to retain and satisfy their human resources which affect the competitiveness of organizations (Tehrani, 2004).

One of the most important factors which can affect employees' satisfaction is the workplace bullying from employers and colleagues. Workplace bullying is known as the negative and unethical issues in the workplace which are sometimes referred to as workplace harassment (Brodsky, 1976), and workplace abuse (Keashly, 1998).

With regard to the fact that all people expect a convenient environment in their workplace, hostile and unethical events will have a nega- 
tive influence on organizational outcomes. These outcomes include employees' morale, employees' work performance and turnover intentions. Bullied employees will not do their predetermined task properly and will not engage in extra-role behaviours which contribute to competitive advantages of the organization. The interaction between employees and customers in the service industry dictates the significant role of employees' outcomes in enhancing the customers' satisfaction level of the service provided (Nadiri \& Tanova, 2010). Therefore, it is quite important to deal with and investigate the bullying phenomenon and address its causes and consequences.

\section{LITERATURE REVIEW}

While, there is no single universally accepted definition of workplace bullying, the formal definition by the Workplace Bullying Institute (WBI, 2014) defined workplace bullying as "repeated, healthharming mistreatment of one or more persons (the targets) by one or more perpetrators. It is an abusive conduct that includes threatening, humiliating, work interference, sabotage and verbal abuse which prevent work from getting done".

Former definitions by authors like Einarsen (2000), Field (1996), Zapf \& Einarsen (2003) provided a wide range and perspectives of bullying practices, inter alia, "social isolation", "verbal aggression", "spreading rumors" and even "attacking attitudes" and "physical violence" which may occur occasionally. However, according to Zapf \& Einarsen (2003) bullying is predominately psychological rather than physical in nature.

Einarsen, Raknes, Matthiesen, \& Hellesoy (1996); Hutchinson, Jackson, Wilkes, \& Vickers (2008) stated that workplace bullying has two main categories which are shaped upon. One of these categories is work-related bullying, which are unwanted repeated actions and practices that are directed to one or more workers. It may cause humiliation, distress, and that may interfere with work performance and create an unpleasant working environment. Work-related bullying behaviors may include an unachievable task, impossible deadlines, unmanageable workloads, meaningless task or supplying unclear information, threat about security etc. (Hutchinson et al., 2008).

The other category is person-related bullying which is regarded as a form of stress that is capable of causing negative effects on employees health, probably leads to psychophysical symptoms, psychiatric trouble such as anxiety-depression disorder, chronic adjustment disorder and post-traumatic stress disorder. Person-related bullying behaviors are ignoring, insulting, public humiliation, spreading rumors or gossips, and intruding on privacy, yelling etc. (Ramsay, Troth, \& Branch, 2010).

The consequences of workplace bullying are significant and cannot be overlooked. The negative effects on individuals lower self-esteem, stress, anxiety, fatigue, burnout and depression (O'Moore, Seigne, \& McGuire, 1998; Zapf, 1999; Mikkelsen \& Einarsen, 2001;Vartia, 2001; Vartia \& Hyyti, 2002; Namie, 2003; Cassitto, Fattorini, Gilloli, Rengo, \& Gonik, 2004; Agervold \& Mikkelsen, 2004; Djurkovic, McCormack, \& Casimir, 2008; Harvey, Stoner, Hochwarter, \& Kacmar, 2007; Matthiesen \& Einarsen, 2001; Lutgen-Sandvik, Alberts, \& Tracy 2008). Moreover, bullying is also associated with threats to individual identity (LutgenSandvik et al., 2008) and post-traumatic stress disorder (Kudielka \& Kern, 2004; Scott, Blanshard, \& Child, 2008).

Outside work environment, bullying can also affect the quality of employees' life and is associated with increasing feelings of powerlessness and reducing the feelings of personal dependence and control (O’Connell, Calvert, \& Watson, 2007).

Workplace bullying has also detrimental consequences for the organization. Targets of workplace bullying have a higher rate of absenteeism, less job satisfaction, organizational commitment and work motivation, in addition to the likelihood of leaving the organization (Keashly \& Neuman, 2005; Agervold \& Mikkelsen, 2004; Burnes \& Pope, 2007; Harvey et al., 2007; O'Connell et al., 2007; Sheehan, McCarthy, \& Kearns, 1998; O'Connell \& Kung, 2007).

As a result of the negative consequences of workplace bullying on both individuals and organiza- 
tions, a real need to respond to combat bullying has become a necessity. Attempts to deal with this phenomenon include identifying the essence of the term and scope (Lutgen-Sandvik, 2006; Namie, 2006). Another step is documenting formal and informal complaints, as targets may tend to report a formal complaint (Macintosh, 2006, Namie \& Namie, 2000; Lutgen-Sandvik, 2006).

At the organizational level, commitment of management at all levels to handle this phenomenon is essential (Tehrani, 2001). Further steps may require engagement of all levels of management to assess the current communication environment, determining areas for improvement, and implementing changes (Keashly \& Neuman, 2005). In addition, developing anti-bullying policies as organizations may wish to create an explicit anti-bullying policy (Richards \& Daley, 2003). Finally, organizations may consider training to enable employees to recognise bullying practices and to protect those who reported bullying acts (Keashly \& Neuman, 2005).

It is often a challenge for hospitality industry management to maintain employees' morale at a high level so as to retain them, and offer the efficient, good service that customers expect (Cheng, 1995). Regarding employees work performance, every organization performs its task with the help of resources as human resources, machine, materials and money. It is universally acknowledged that work performance is the most important variable considered in industrial and organizational psychology research (Borman, 2004; Farh, Seo, \& Tesluk, 2012; Kacmar, Harris, Collins, \& Judge, 2009). This is based on the fact that job performance has always been reported as a significant indicator of organizational performance regardless of how it is conceptualised (Einarsen, Hoel, Zapf, \& Cooper, 2010).

Regarding employees turnover intentions, the hospitality sector is one of the world's fastestgrowing industries. According to Cho, Johanson, \& Guchait (2009) and Riley (2006), turnover intentions imply to one's intention to leave his employing organisation which shows a breach in the relationship between employees and the organization. The costs of turnover include opportunity cost, retraining and reselection and decrease in the morale of current employees which may result in serious losses to the firms (Cho et al., 2009).

\section{STATEMENT OF THE PROBLEM}

Bullying often involves an abuse or misuse of power. In addition bullying behavior creates feelings of defenseless and injustice in the target and undermines an individual's right to dignity at work, which may lead to reducing morale, performance and finally to leave work. Therefore, the problem of the study can be stated in the following question "what are the impacts of workplace bullying on the organizational outcomes, which are embodied in employees' morale, work performance and turnover intentions?".

\subsection{Objectives of the study}

This study has three specific objectives:

1. To explore the phenomenon of workplace bullying and deepen the understanding of such negative behavior.

2. To investigate the extent to which workplace bullying can affect the organizational outcomes (employees' morale, work performance and turnover intentions).

3. To propose practical strategies for practitioners to assist them in preventing/avoiding workplace bullying if it occurs.

\subsection{The Research Hypotheses}

The research hypotheses can be formulated as follows (figure 1):

H1: Workplace bullying has a significant negative impact on employees' morale.

H1a: Work-related bullying has a significant negative impact on employees' morale.

H1b: Person-related bullying has a significant negative impact on employees' morale.

H2: Workplace bullying has a significant negative impact on employees' work performance.

H2a: Work-related bullying has a significant negative impact on employees' work performance. 
H2b: Person-related bullying has a significant negative impact on employees' work performance.

H3: Workplace bullying has a significant influence on turnover intentions of employees.

H3a: Work-related bullying has a significant influence on turnover intentions of employees. H3b: Person-related bullying has a significant influence on turnover intentions of employees.

H4: Workplace bullying has a significant impact on employees, according to their demographic data (gender, age and educational level).

\section{METHODOLOGY}

The researchers have considered the descriptive analytical approach to deepen the understanding and investigate the phenomenon of workplace bullying that may occur within a selected sample of hotel operations. The descriptive method assisted in developing the hypothesis of the study, and subsequently, the analytical approach was used for testing their validity. The data collection instrument involved questionnaire surveys to test hypotheses and answer questions (Collis \& Hussey, 2009). As a result, the methodology employed two main phases; desk research and field research. The desk re- search was used to collect data and form the hypothetical background of the workplace bullying phenomenon.

The population of the study consisted of all fivestar hotels in Egypt which amount to 156 fivestar hotels (EHA, 2012). A purposive sample of 47 five-star hotel operations was selected representing $30 \%$ of the total population in two main Egyptian tourist regions namely, Sharm-Elsheikh and Alexandria. The target respondents were 30\% of the mean calculation of a total number of department employees in each of the selected sample population.

The field research used two forms of questionnaires in order to test the hypotheses of the study. The first was directed to both, front- and back-ofthe-house employees, selecting a random sample of bell desk employees and kitchen stewards to address the hypotheses of the research. All the sample respondents have the same nationality (Egyptian citizens) due to the fact that the type of the jobs they undertake requires low skill level. Therefore, local staff is employed and no expats are recruited for such jobs. The second questionnaire was addressed to the managers of the selected group of respondents to evaluate the respondents' work performance.

The first questionnaire was distributed to an equal random sample of 10 employees (five em-

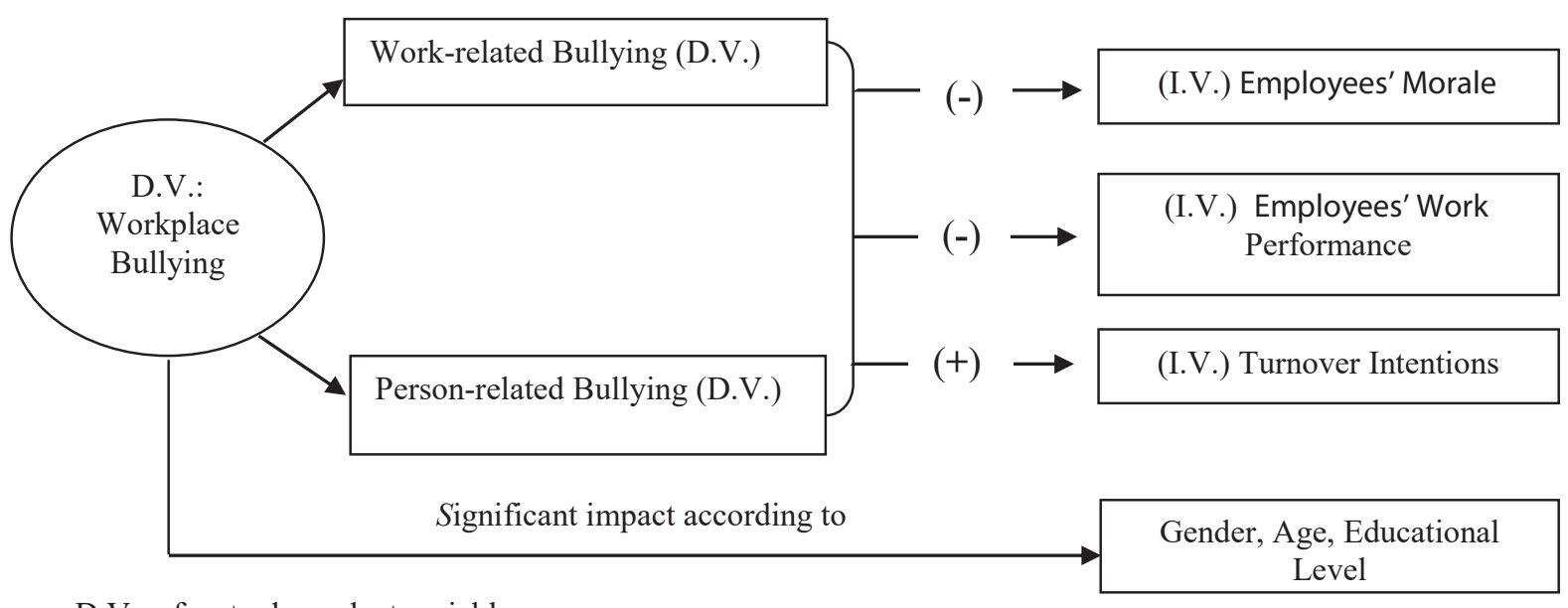

D.V. refers to dependent variable

I.V. refers to independent variable.

Figure 1. Hypothetical Model of the Research 
ployees working at the back-of-the house and five employees working at the front-of-the house). Only three hundred and four questionnaires were valid for analysis out of the 470 questionnaires sent out for the survey. A five-point Likert scale was used for all the statements included in the two questionnaires. The first questionnaire contained five main sections; measuring workrelated bullying, personal-related bullying, employees' morale, employees' leaving intention, and finally collecting demographic information about the respondents. The second questionnaire contained only one section, asking managers to evaluate the respondents' work performance. Response categories ranged from 1 (strongly disagree) to 5 (strongly agree) in both questionnaire surveys.

Before the distribution of the questionnaires, a pilot stage was considered to uncover any difficulties which respondents may face while answering the questions. A number of 10 hotel employees and 6 departments' managers were contacted to answer the pilot form of the questionnaires and give their feedback about the clarity of wording, layout and correlation of the questions. The result of the pilot test revealed confusion of some of the words in the employees' questionnaire. Hence, the researchers provided an Arabic translation for all the questions to avoid misperception and to get reliable answers. There were no negative comments as regards the managers' questionnaire. All the pilot survey participants were excluded from the selected sample.

\section{RESULTS ANALYSIS}

The Spearman correlation coefficient and other statistical tests such as Mann Whitney were used to test the study's hypotheses. The Statistical Package for Social Sciences (SPSS, version 20) program for Windows was used to interpret the results. A reliability analysis (Cronbach's Alpha) was conducted to ensure the validity and reliability of the questionnaire items. All values of Cronbach's alpha for constructs were considerably high indicating that the reliability and validity of all constructs used in this study were supported. Results are presented in Table (1).
Table 1. Reliability and validity test using Cronbach's Coefficient Alpha

\begin{tabular}{|c|c|c|c|}
\hline Measures & $\begin{array}{l}\text { No. } \\
\text { of Items }\end{array}$ & $\begin{array}{l}\text { Cronbach's } \\
\text { Alpha }\end{array}$ & Validity \\
\hline $\begin{array}{l}\text { Overall } \\
\text { Questionnaire }\end{array}$ & 55 & .873 & .934 \\
\hline $\begin{array}{l}\text { Workplace } \\
\text { Bullying }\end{array}$ & 21 & .868 & .931 \\
\hline $\begin{array}{l}\text { Work-related } \\
\text { Bullying }\end{array}$ & 10 & .795 & .891 \\
\hline $\begin{array}{l}\text { Person-related } \\
\text { Bullying }\end{array}$ & 11 & .719 & .847 \\
\hline $\begin{array}{l}\text { Employees' } \\
\text { Morale }\end{array}$ & 8 & .840 & .916 \\
\hline $\begin{array}{l}\text { Employees' } \\
\text { Performance }\end{array}$ & 23 & .798 & .891 \\
\hline $\begin{array}{l}\text { Turnover } \\
\text { Intentions }\end{array}$ & 3 & .714 & .844 \\
\hline
\end{tabular}

Table 2 presents the Spearman correlation coefficient which was interpreted in terms of its statistical significance to $\mathrm{p}$-values (probabilities of relationships). The first hypothesis which test the impact of overall workplace bullying on employees' morale had a significant correlation with a value of -.263 and $P=.001$. The results also showed a significant correlation between work-related bullying, person-related bullying and morale.

As regard the impact of overall workplace bullying on employees' performance, results showed no correlation between the two variables, as P-value recorded .059. Results also showed that work-related bullying was correlated to work performance based on a record of $P$-value of 0.182 . On the other hand, no correlation was valid between personrelated bullying and work performance as the $P$-value was 0.103 .

As regard the third hypothesis, the influence of overall workplace bullying on employees turnover intentions demonstrated a very significant correlation with a value of $0.649(P=.000)$. More specifically, results proved a significant correlation between work-related bullying, person-related bullying and turnover intentions, as it recorded a value of .651 $(P=.000)$, and $0.561(P=.000)$ respectively. 
Table 2. Correlation between workplace bullying and morale, performance and turnover intentions

\begin{tabular}{l|c|c|c}
\hline \multicolumn{1}{c}{ Workplace bullying } & Morale & Performance & Turnover intentions \\
\hline Overall bullying & & & \\
Spearman correlation & $-.263^{* *}$ & .147 & $.649^{* *}$ \\
\hline Sig. (2-tailed) & .001 & .059 & .000 \\
\hline Work-related bullying & $-.267^{* *}$ & $.182^{*}$ & $.651^{* *}$ \\
\hline Spearman correlation & .001 & .020 & .000 \\
Sig. (2-tailed) & & .103 & $.561^{* *}$ \\
\hline Person-related bullying & $-.245^{* *}$ & .189 & .000 \\
\hline Spearman correlation & .002 & & \\
\hline Sig. (2-tailed) & & \\
\hline
\end{tabular}

Note: ${ }^{*}$ Correlation is significant at the .01 level (2-tailed). ${ }^{\star}$ Correlation is significant at the 0.05 level (2-tailed).

The respondents' profile which is shown in Table 3 contains the different characteristics of the sample as gender, age, and educational level and department. Table 4 presents the correlation between workplace bullying and gender which recorded -.219 and a value of $P=.005$, which is considered significant. Besides there was a correlation between workplace bullying and respondents' age, as Spearman correlation recorded 0.156 with value of $P=0.046$. Finally, there was no correlation between workplace bullying and educational level, based on Spearman Correlation of 0.147 and a value of $P=0.059$.
Table 4. Correlation between workplace bullying and demographic data for respondents

\begin{tabular}{|c|c|c|c|}
\hline $\begin{array}{l}\text { Workplace } \\
\text { Bullying }\end{array}$ & Gender & Age & $\begin{array}{c}\text { Educational } \\
\text { Level }\end{array}$ \\
\hline $\begin{array}{l}\text { Spearman } \\
\text { Correlation }\end{array}$ & $-.219 * *$ & $.156^{*}$ & .147 \\
\hline Sig. (2-tailed) & .005 & .046 & .059 \\
\hline
\end{tabular}

Note: ${ }^{*}$ Correlation is significant at the .01 level (2-tailed). ${ }^{*}$ Correlation is significant at the 0.05 level (2-tailed).

Table 3. Respondents' Profile

\begin{tabular}{|c|c|c|}
\hline Item & No of employees & $\%$ \\
\hline \multicolumn{3}{|l|}{ Gender } \\
\hline Male & 146 & 88.5 \\
\hline Female & 19 & 11.5 \\
\hline \multicolumn{3}{|l|}{ Age } \\
\hline $20-30$ & 135 & 81.5 \\
\hline $31-40$ & 30 & 18.5 \\
\hline Over 40 & 00 & 00 \\
\hline \multicolumn{3}{|l|}{ Educational level } \\
\hline Non-educated & 51 & 31 \\
\hline Middle-level Education & 88 & 53.3 \\
\hline University Graduate & 26 & 15.8 \\
\hline \multicolumn{3}{|l|}{ Department } \\
\hline Front-of-the-house employees & 100 & 60.6 \\
\hline Back-of-the-house employees & 65 & 39.4 \\
\hline
\end{tabular}




\section{CONCLUSION}

The main aim of the study was to determine the impact of workplace bullying on employees' morale, performance and turnover intentions. The research findings are consistent with those of Rayner (2007); Agervold \& Mikkelsen (2004); Einarsen et al. (2010); Lewis (2007), who found significant effects of workplace bullying on the multiple organisational outcomes including morale and turnover intentions. Other drawbacks of these practices include undermining teamwork, lowering productivity and increasing staff sickness, absence and turnover rates. It also costs time and money, affects the quality of service delivery, and damages the organization's reputation (Cauley, 2014).

The research results were also consistent with the findings of Buchanan (2013), which indicated that people who are working in the hospitality industry are highly affected by bullying acts. The influence includes negative impact on employees' job security, potential career advancement and healthy working environment.

Regarding employees work performance, the research findings revealed that there was no correlation between workplace bullying and employees' work performance. The present research findings disagreed with the research findings of Namie (2003) and Judith (2008) as bullying acts have a negative impact on employees' job performance due to the stressful working atmosphere for and the creation of job dissatisfaction and consequently the loss of productivity for the organisation. Moreover, the present research findings also contradict with the findings of Yahaya, Ing, Lee, Yahaya, Boon, Hashim, \& Taat (2012) which indicated that person-related bullying influences negatively employees' productivity level. The main reasons behind this contradiction relates to the challenging motivation and spirit that these nuances may create and the disposition that the employee may have in order to prove himself/herself as worthwhile, productive and top performer.

Regarding the influence of workplace bullying on employees turnover intentions, the research findings recorded a very strong correlation that workplace bullying has a negative influence on employees' turnover intentions. This finding agreed with the findings of Hogh, Hoel, \& Caniero (2011); Tanova \& Holtom (2008) which suggested that the risk of turnover increase with frequency of exposure to bullying practices as those intentions may provide the bullied with some psychological protection from the bullying behavior. The risk of turnover was three times higher among the frequently bullied and 1.6 times higher among the occasionally bullied compared with the non-bullied respondents. Further, the study found that turnover intentions are actually stronger in those that do not experience the bullying. This may be due to the fact that their own treatment provides a standard against which the discrepancy in treatment can be measured; highlighting the level of mistreatment being inflicted on others in the workplace.

Generally speaking, it was obvious that the three independent variables of the research which are "employees' morale, work performance and turnover intentions" develop consequently. There was also a lack of awareness about bullying practices which the term encompasses, which often prevents people from realizing that a boss or co-worker is a bully.

In addition, regarding the relationship between workplace bullying and demographic data for respondents, the results of the current research indicated that there is a correlation between workplace bullying and employees' gender and age. This result is consistent with studies done by Di Martino, Hoel, \& Cooper (2003); Ariza-Montes, Muniz, Montero-Simo, \& Araque-Padil (2013), O'Connell et al. (2007) which indicated that employee's response to bullying behaviours are affected by their demographic data including age, gender and educational level. On the other hand, it contradicts with the results of Sheehan (1999); Hogh et al. (2011) and O’Connell \& Kung (2007). 
Finally, all studies on employees' bullying provided useful information for the hospitality service management to improve and develop procedures to enhance the morale level of hospitality employees, to reduce absenteeism and turnover rates, to boost their awareness of the negative consequences of workplace bullying, to implement appropriate mechanisms to decrease the phenomenon of workplace bullying and to improve the employees' workplace environment. As a result, the management will be able to provide a convenient motivational approach to maintain morale, support employees to achieve their goals and those of the organisation as well.

\section{FURTHER RESEARCH}

The current research investigated the impact of workplace bullying in five-star hotels in just two main touristic destinations in Egypt. Further research can enlarge the sample size to investigate the impact on other hotel categories like three or four-star hotels in more geographic areas and even in other sectors of the hospitality industry. Additionally, this research focused on a particular segment of the hospitality workforce i.e. bellmen and stewards. It would be a good opportunity to investigate other segments of employees, e.g. housekeeping, food and beverage staff and others. Furthermore, other variables rather than employees' morale, performance and turnover intentions could be investigated to deepen the understanding of the effects of workplace bullying which can affect the work environment, for instance, job satisfaction, employees' loyalty and further the potential impact on personnel health. Further research can also be extended to investigate the impact of workplace bullying on customer relations and satisfaction. Moreover, it should also investigate how the workplace bullying phenomenon impacts on inter-departmental/colleagues communications and work relations.

\section{REFERENCES}

1. Agervold, M. \& Mikkelsen, E. (2004). Relationships between Bullying, Psychosocial Work Environment and Individual Stress Reactions. International Journal of Hospitality Management, 18(4), 336-351.

2. Ariza-Montes, A., Muniz, N., Montero-Simo, M., \& AraquePadil, R. (2013). Workplace Bullying among Healthcare Workers. International Journal of Environmental Research and Public Health, 10(8), 3121-3139.

3. Borman, W. C. \& Motowidlo, S. J. (2004). Organizational Citizenship Behavior and Contextual Performance.

4. Brodsky, C. M. (1976). The Harassed Worker. Toronto, Canada: Lexington Books.

5. Buchanan, A. (2013). The Ethics of Revolution and Its Implications for the Ethics of Intervention. Philosophy \& Public Affairs, 41(4), 291-323.
6. Burnes, B. \& Pope, R. (2007). Negative Behaviors in the Workplace: A Study of Two Primary Care Trusts in the NHS International Journal of Public Sector Management, 20(4), 285-303.

7. Cassitto, M. G., Fattorini, E., Gilloli, R., Rengo, C. \& Gonik, V. (2004). Raising Awareness of Psychological Harassment at Work for Protecting Workers' Health. Geneva, Switzerland: World Health Organization.

8. Cauley, C. (2014). Workplace Bullying Companies Realizing the Impact of Bullying on Morale, Productivity. Retrieved from http://www.bizjournals.com (4th October, 2014).

9. Cheng, H. (1995). Assessing the Importance of Employee Motivation in the Hotel Industry in Taiwan. Unpublished Master's thesis. Menomonie, Wisconsin, USA: University of WisconsinStout.
10. Cho, S., Johanson, M., \& Guchait, P. (2009). Employees Intent to Leave: A Comparison of Determinants of Intent to Leave versus Intent to Stay. International Journal of Hospitality Management, 28(3), 374-381.

11. Collis, J., \& Hussey, R. (2009)

( $3^{\text {rd }}$ Ed.). Business Research: a Practical Guide for Undergraduate and Postgraduate Students. UK: Palgrave Macmillan Publisher Ltd.

12. Di Martino, V., Hoel, H., \& Cooper, C. (2003). Preventing Violence and Harassment in the Workplace. Dublin: European Foundation for the Improvement of Living and Working Conditions.

13. Djurkovic, N., McCormack, D. \& Casimir, G. (2008). Workplace Bullying and Intention to Leave: The Moderating Effect of Perceived Organizational Support. Human Resource Management Journal, 18(4), 405-422. 
14. EHA - Egyptian Hotel Association (2012). Egyptian Hotel Guide (32 ${ }^{\text {nd }}$ Ed.). Cairo: Egyptian Hotel Association.

15. Einarsen, S. (2000). Harassment and Bullying at Work: A Review of the Scandinavian Approach. Journal of Aggression and Violent Behavior, 5(4), 379-401.

16. Einarsen, S., Hoel, H., Zapf, D., \& Cooper, C. (Ed.) (2010) ( $2^{\text {nd }}$ Ed.). Organizational Effects of Workplace Bullying and Harassment in the Workplace: Developments in Theory, Research, and Practice, Boca Raton: CRC Pesss, 1-40.

17. Einarsen, S., Raknes, B., Matthiesen, S., \& Hellesoy, O. (1996). Bullying at Work and its Relationship with Health Complaints - Moderating Effects of Social Support and Personality. Norilsk Psychology, 48(2), 116-137.

18. European Journal of Work and Occupational Psychology, 10(4), 375-392.

19. European Journal of Work and Organizational Psychology, 10, 393-413.

20. Farh, C., Seo, M-G., \& Tesluk, P. (2012). Emotional Intelligence, Teamwork Effectiveness, and Job Performance: The Moderating Role of Job Context. Journal of Applied Psychology, 94(4), 890-900.

21. Field, T. (1996). Bully in Sight: How to Predict, Resist, Challenge and Combat Workplace Bullying. Oxfordshire, UK: Success Unlimited.

22. Harvey, P., Stoner, J., Hochwarter, W., \& Kacmar, C. (2007). Coping with Abusive Supervision: The Neutralizing Effects of Ingratiation and Positive Affect on Negative Employee Outcomes. Leadership Quarterly, 18(3), 264-280.

23. Hogh, A., Hoel, H., \& Carneiro, I. (2011). Bullying and Employee Turnover among Healthcare Workers: A Three-wave Prospective Study. Journal of Nursing Management, 19(6), 742-751.

24. Hutchinson, M., Jackson, D., Wilkes, L., \& Vickers, M. (2008) A New Model of Bullying in the
Nursing Workplace: Organizational Characteristics as Critical Antecedents. Advances in Nursing Science Journal, 31(2), 60-71.

25. International Journal of Manpower, 20(1), 70-85.

26. Journal of Communication Monographs, 73(4), 406-433.

27. Journal of Human Performance, 10(2), 67-70.

28. Judith, L. (2008). Workplace Bullying: Aggressive Behavior and its Effect on Job Satisfaction and Productivity. A Dissertation presented in partial fulfillment of the requirements for the degree doctor of management in organizational leadership. USA: University of Phoenix.

29. Kacmar, K. M., Harris, K. J., Collins, B. J., \& Judge, T. A. (2009). Core Self-evaluations and Job Performance: The Role of the Perceived Work Environment. Journal of Applied Psychology, 94(6), 1572-1580.

30. Keashly, L. (1998). Emotional Abuse in Workplace: Conceptual and Empirical Issues. Journal of Emotional Abuse, 1, 85-117.

31. Keashly, L., \& Neuman, J. H. (2005). Bullying in the Workplace: Its Impact and Management. Employee Rights and Employment Policy Journal, 8(3), 335-373.

32. Kudielka, B. M. \& Kern, S. (2004) Cortisol Day Profiles in Victims of Mobbing (Bullying at the Workplace): Preliminary Results of a First Psychobiological Field Study. Journal of Psychosomatic Research, 56(1), 149-150.

33. Lewis, D. (2007). Workplace Bullying in the Public Sector: Understanding the Racial Dimension. Public Administration, 85(3), 641-665.

34. Lutgen-Sandvik, P. (2006). Take This Job and Quitting and Other Forms of Resistance to Workplace Bullying.

35. Lutgen-Sandvik, P., Alberts, J. K., \& Tracy, S. J. (2008). The Communicative Nature of Workplace Bullying and Responses to Bullying. Paper presented at the Western States Communication
Association Annual Convention, Denver/Boulder, CO.

36. Macintosh, J. (2006). Tackling Workplace Bullying. Issues in Mental Health Nursing, 27(6), 665-679.

37. Matthiesen, S. B., \& Einarsen, S. (2001). Accounts of Workplace Bullying: The Role of the Organization.

38. Mikkelsen, E. G., \& Einarsen, S. (2001). Bullying in Danish Work-life: Prevalence and Health Correlates.

39. Nadiri, H. \& Tanova, C. (2010). An Investigation of the Role of Justice in Turnover Intentions, Job Satisfaction, and Organizational Citizenship Behavior in Hospitality Industry. International Journal of Hospitality Management, 29, 33-41.

40. Namie, G. (2003). Workplace Bullying: Escalated Incivility. Ivey Business Journal, 68(8), 1-6.

41. Namie, G. (2006). Bully Busters: Guide to Citizen Lobbying. Bellingham, WA: The Workplace Bullying Institute.

42. Namie, G., \& Namie, R. (2000). The Bully at Work: what you can do to stop the hurt and reclaim your dignity on the job. Naperville, IL: Sourcebooks.

43. O'Connell, M. \& Kung, M-C (2007). The Cost of Employee Turnover. International Management Journal, 49(1), 14-19.

44. O'Connell, P., Calvert, E. \& Watson, D. (2007). Bullying in the Workplace: Survey Reports. Ireland The Economic and Social Research Institute.

45. O'Moore, M., Seigne, E. \& McGuire, L. (1998). Victims of Workplace Bullying in Ireland. Irish Journal of Psychology, 19(2-3), 345-357.

46. Ramsay, S., Troth, A. \& Branch, S. (2010). Workplace Bullying: A Group Processes Framework. Journal of Occupational and Organizational Psychology, 84(4), 799-816.

47. Rayner, C. (2007). The Incidence of Workplace Bullying. Journal of Community and Applied Social Psychology, 7(3), 199-208. 
48. Richards, J. \& Daley, H. (2003) Bullying Policy: Development, Implementation and Monitoring. In S. Einarsen, H. Hoel, D. Zapf, \& C. L. Cooper (Eds.). Bullying and Emotional Abuse in the Workplace: International Perspectives in Research and Practice. London: Taylor-Francis, 237-269.

49. Riley, D. (2006). Turnover Intentions: The Mediation Effects of Job Satisfaction, Affective Commitment and Continuance Commitment. Unpublished Master Thesis. Hamilton, New Zealand: University of Waikato.

50. Scott, J., Blanshard, C. \& Child, S. (2008). Workplace Bullying of Junior Doctors: A Cross-Sectional Questionnaire Survey. The New Zealand Medical Journal, 121(12), 10-14.

51. Sheehan, M. (1999). Workplace Bullying: Responding with Some Emotional Intelligence. International Journal of Manpower, 20(1), 57-69.

52. Sheehan, M., McCarthy, P., \& Kearns, D. (1998). Managerial
Styles during Organizational Restructuring: Issues for Health and Safety Practitioners. Journal of Occupational Health and Safety in Australia and New Zealand, 14(1), 31-37.

53. Tanova, C. \& Holtom, B. (2008). Using Job Embeddedness Factors to Explain Voluntary Turnover in Four European Countries. The International Journal of Human Resource Management, 19(9), 1553-1568.

54. Tehrani, N. (2001). A Total Quality Approach to Building a Culture of Respect. In N., Tehrani (Ed.), Building a Culture of Respect: Managing Bullying at Work. London: Taylor \& Francis, 135-154.

55. Tehrani, N. (2004). Bullying: A Source of Chronic Posttraumatic Stress. British Journal of Guidance and Counseling, 32, 357-366.

56. Vartia, M. \& Hyyti, J. (2002). Gender Differences in Workplace Bullying among Prison Officers. European Journal of Work and Organizational Psychology, 11(1), 113-126.
57. Vartia, M. (2001). Consequences of Workplace Bullying with Respect to the Wellbeing of its Targets and the Observers of Bullying. Scandinavian Journal of Work Environment and Health, 27, 63-69.

58. WBI - Workplace Bullying Institute (2014). 2014 WBI: U.S. Workplace Bullying Survey. USA: Workplace Bullying Institute.

59. Yahaya, A., Ing, T., Lee, G., Yahaya, N., Boon, Y., Hashim, S., \& Taat, S. (2012). The Impact of Workplace Bullying on Work Performance. Archives Des Sciences, 65(4), 18-28.

60. Zapf, D. \& Einarsen, S. (2003). Individual Antecedents of Bullying. In: S. Einarsen, H. Zapf, \& D. Cooper (Eds.). Bullying and Emotional Abuse in the Workplace: International Perspectives in Research and Practice. London: Taylor \& Francis, 165-184.

61. Zapf, D. (1999). Organizational Work Group Related and Personal Causes of Mobbing Bullying at Work. 


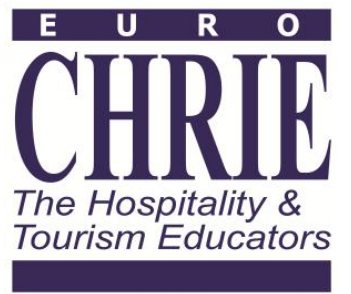

\section{Institute} of Hospitality

This is to certify that

\section{Ashraf A. Tag-Eldeen}

Alexandria University and SRH Hochschule Berlin

\section{Mona Barakat and Hesham Dar}

Alexandria University

were shortlisted for the

\section{Institute of Hospitality \\ Education Research Award 2016}

for their paper titled

"Investigating the Impact of Workplace Bullying on Employees' Morale, Performance and Turnover Intentions in Five-star Egyptian Hotel Operations"

This award commends an individual piece of research that has made a significant contribution to the hospitality industry and to education

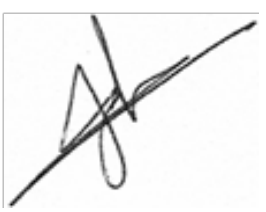

Dr John Fong

President

EuroCHRIE 2016 - 2017

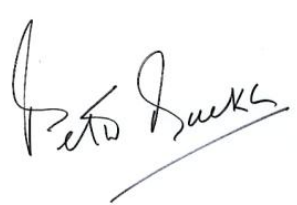

Peter Ducker FIH

Chief Executive

Institute of Hospitality 